\title{
Characteristics and Factors that Influence the Purchase of Beef During the Covid 19 Pandemic in Yogyakarta, Indonesia
}

\author{
Tri Anggraeni Kusumastuti ${ }^{1, *}$ and Rini Widiati ${ }^{1}$
}

\author{
${ }^{1}$ Department of Livestock Social Economics, Faculty of Animal Science, Universitas Gadjah Mada, Yogyakarta, \\ Indonesia, Jl. Fauna No, Bulaksumur, Yogyakarta, Indonesia \\ ${ }^{*}$ Corresponding author. Email: trianggraeni@ugm.ac.id
}

\begin{abstract}
This study aims to identify consumer characteristics of beef purchases and analyze the factors that influence the purchase of beef products during the pandemic in Yogyakarta, Indonesia. The research was conducted in Depok District, Sleman Yogyakarta Regency, with the consideration that the distribution of patients infected with the highest positive virus was in Yogyakarta. The study was conducted from May to June 2020. The respondents were 200 mothers who worked or took care of stairs using the snowball sampling technique. To identify the characteristics of the purchase of beef products, it was carried out descriptively quantitatively. Multiple Linear Regression Analysis was used to analyze the factors that influence the amount of beef expenditure. The regression equation was estimated using Ordinary Least Square methods. The results showed that during the pandemic consumers prefer fresh beef because consumers were more satisfied if they can choose meat directly in the market. Meatballs and sausages that were in demand were processed beef because they were practical and affordable. The independent variables of mother's education and income show a positive and significant effect on the purchase of beef. On the other hand, it is necessary to improve health protocols to be firmer in the market because of the high interest in purchasing products directly to the market.
\end{abstract}

Keywords: Covid-19, purchasing beef, consumer characteristics.

\section{INTRODUCTION}

The need for beef consumption by the Indonesian population tends to continue to increase in line with the increasing population of Indonesia and public awareness of the importance of animal protein, so that the rate of demand for beef [1]. The Covid-19 pandemic that occurred throughout Indonesia in March 2020 has caused the national demand for beef to decline as a result of the implementation of large-scale social distancing, physical distancing and social restrictions. Since Indonesia was infected with the Covid-19 virus, there have been various efforts to reduce the rate of transmission of this virus. One of the efforts made by the government is the implementation of large-scale social restrictions (PSBB) policies [2]. The decrease in beef consumption was due to, among others, a decrease in people's purchasing power and the prohibition of social activities that involve large numbers of people and have an impact on the number of purchases, references, and ways of purchasing products.
Education, income, number of family members are factors that influence product purchasing decisions. This study aims to identify consumer characteristics and analyze the factors that influence the purchase of beef products during the pandemic in Yogyakarta, Indonesia as one of the red zone areas in Indonesia. Yogyakarta is one of the cities that has a fairly high number of positive Covid-19 cases and is included in the red zone area [3].

\section{MATERIAL AND METHOD}

\subsection{Material}

The research was conducted in Sleman Regency. This was based on the consideration that Sleman Regency was the district with the most positive cases of corona compared to other areas in Yogyakarta. The sample was aimed at maternal consumers or women who were married. Based on the considerations of housewives, both those who work and take care of the household, were the determinants of purchasing animal protein products. 


\subsection{Method}

Determination of the sample using the snowball sampling method. This technique was used because there was no valid data on the population that consumes meat. The sample was aimed at consumers or women who were married. Based on the considerations of housewives, both those who work and take care of the household, were the determinants of purchasing animal protein products. Determination of the sample using the snowball sampling method. The primary data collection method was carried out on a sample of respondents using the interview method with the help of a closed questionnaire. The questionnaire contains questions covering the characteristics of product purchases and factors that influence the purchase of beef products. Secondary data were collected from agencies related to research, namely the Central Bureau of Statistics, the Ministry of Industry and Trade, and the Livestock Service Office of Sleman Regency.

To identify the characteristics of beef purchases (kg/month), it was carried out descriptively. The results of the analysis are written in tabular form. To analyze the factors that affect the amount of beef expenditure, Multiple Linear Regression Analysis is used with the following equation:

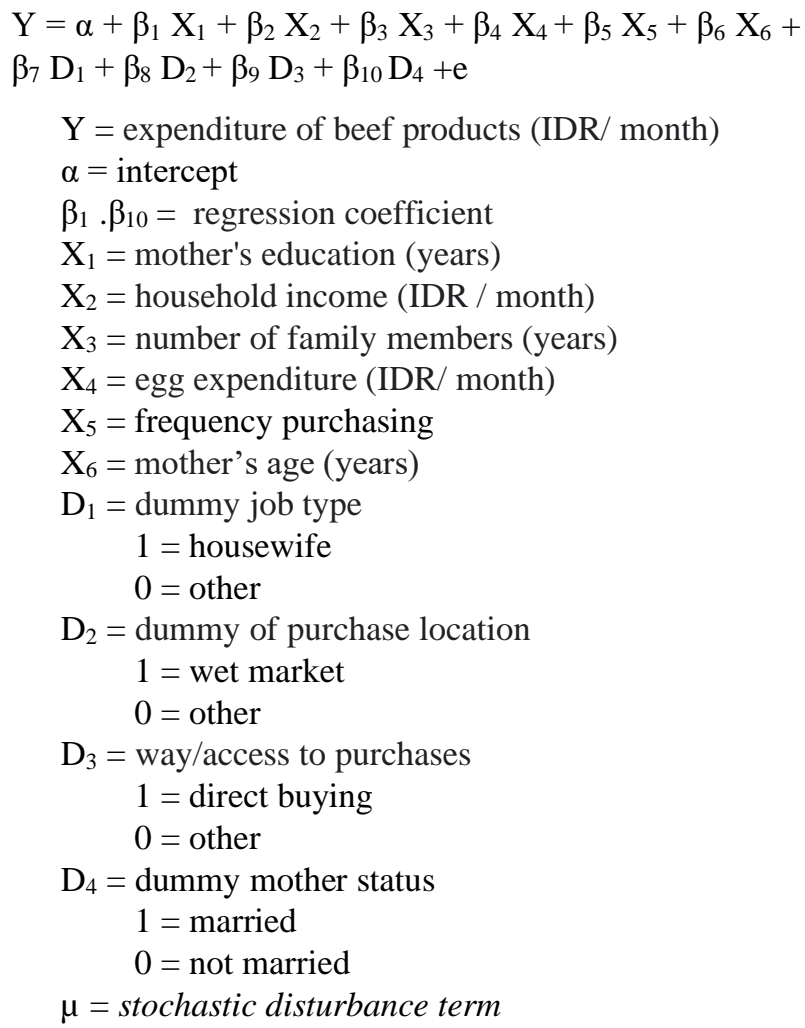

The regression equation was estimated using OLS (Ordinary Least Square) methods. To test the hypothesis using the coefficient of determination $\left(\mathrm{R}^{2}\right), \mathrm{F}$ test and $\mathrm{t}$ test [4].

\section{RESULT AND DISCUSSION}

\subsection{Beef Purchasing Characteristics}

Consumers prefer fresh meat $(51 \%)$ because consumers are more satisfied if they can choose meat directly at the market and this is a habit for housewives (Figure 1). Consumers prefer to buy fresh meat by coming directly to the seller because consumers can choose and see the quality of fresh meat directly [5]. Consumers can see the physical characteristics of fresh meat directly before buying [6]. Consumers prefer to shop directly at the market because of the opportunity to bargain, and they can carry out the meat selection process independently [7].

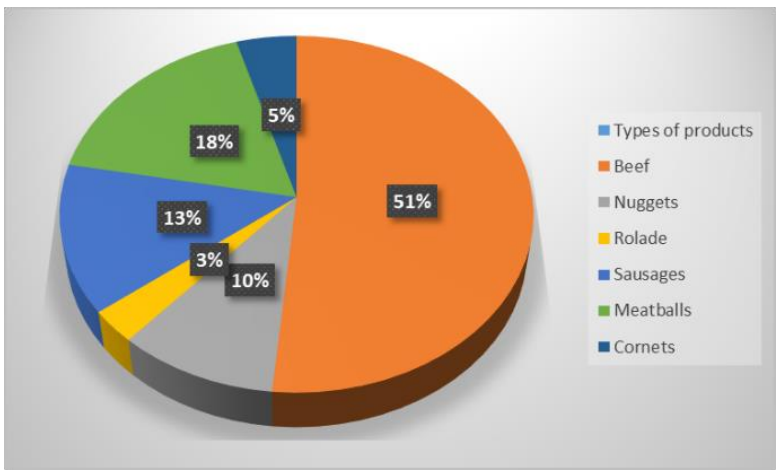

Figure 1. Types of products

The most popular processed beef products are meatballs and sausages because they are practical and affordable compared to other beef preparations (Figure 2). Consumption of frozen food products increases along with the increase in Covid-19 cases. Frozen food products during the Covid-19 pandemic can provide convenience for consumers. The types of frozen food processed beef products that are generally most consumed are nuggets, meatballs, and sausages [8].

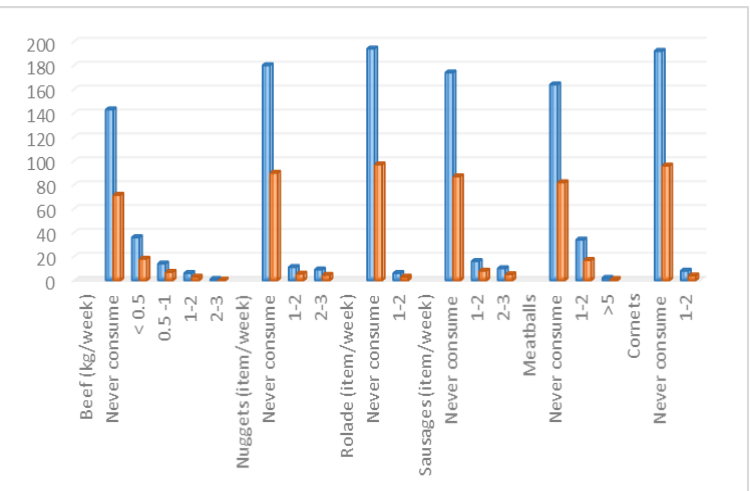

Figure 2. Amount of consumption

Consumers prefer to buy directly on the wet market $(85 \%)$. On the other hand, the market is a location that is vulnerable to the Covid-19 cluster because many people gather. Wet markets are one of the clusters for the spread of Covid-19 in a number of areas. Traditional markets are one of the places that are susceptible to infection because 
Table 1. Multiple regression analysis of factors that influence the purchase of beef

\begin{tabular}{|l|c|c|c|c|}
\hline \multicolumn{1}{|c|}{ Variable } & Coefficient & Std. Error & t-Statistic & Prob. \\
\hline C & 10.41400 & 0.613454 & 16.97600 & 0.0000 \\
\hline Mother's education (X1) & 0.671526 & 0.272100 & 2.467938 & 0.0227 \\
\hline Household income (X2) & 0.999954 & 0.219109 & 4.563728 & 0.0002 \\
\hline Number of family members (X3) & -0.435289 & 0.410222 & -1.061106 & 0.3013 \\
\hline Egg expenditure (X4) & -0.005778 & 0.017236 & -0.335236 & 0.7409 \\
\hline Frequency purchasing (X5) & -0.010339 & 0.016810 & -0.615024 & 0.5455 \\
\hline Mother's age (X6) & -0.020839 & 0.044055 & -0.473009 & 0.6413 \\
\hline Dummy of job type (D1) & -0.133621 & 0.243264 & -0.549285 & 0.5889 \\
\hline Dummy of purchase location (D2) & 0.094421 & 0.222295 & 0.424755 & 0.6756 \\
\hline Dummy of way/access to purchase (D3) & 0.147174 & 0.274683 & 0.535795 & 0.5980 \\
\hline Dummy of mother status (D4) & 0.149115 & 0.538483 & 0.276916 & 0.7847 \\
\hline R-squared & 0.722563 & & & \\
\hline Adjusted R-squared & 0.583844 & & & \\
\hline F-statistic & 5.208837 & & & \\
\hline Prob (F-statistic) & 0.000851 & & & \\
\hline
\end{tabular}

the market is a public facility for buying and selling daily needs and many people have activities in these locations who come from various places. Market conditions are also often full where social and physical distancing is difficult to apply [9].

\subsection{Factors that Influence the Purchase of Beef}

Analysis of the factors that influence the purchase of beef using the Ordinary Least Square method with the help of software Eviews version 5.1. The classic assumption test, namely normality, shows that the data is normally distributed, which is indicated by the Jarque Bera prob value $(0.30)>0.05$ so that it is said that the residue is normally distributed. Linearity test with the Ramsey reset test is F stat $(0.12)>0.05$. The multicollinear test results showed a correlation between the independent variables with the value of $r<0.8$ so that the data were free from multicollinear disease. The results of the heteroscedasticity test with the white heteroscedasticity model showed that the value of Obs * R square (15.47)> 0.05 indicated that the data did not contain heteroscedasticity. Likewise, from the results of the deviation analysis serial correlation with the BreuschGodfrey Serial Correlation LM Test model, the value of Obs * R square $(0.965)>0.05$ indicates that the data does not contain serial correlation.

The results of the regression analysis of the factors that influence the purchase of beef can be seen in the following equation:
$\mathrm{Y}=$

$-10.414+\mathbf{0 . 6 7 1 5 2 6} \mathrm{X}_{1}+\mathbf{0 . 9 9 9 9 5 4} \mathrm{X}_{2}+$
$-0.435289 \mathrm{X} 3-0.005778 \mathrm{X} 4-0.010339 \mathrm{X} 5-$
$0.020839 \mathrm{X} 6-0.133621 \mathrm{D} 1+0.094421 \mathrm{D} 2$
$+0.147174 \mathrm{D} 3+0.149115 \mathrm{D} 4+\mathrm{e}$

The adjusted $\mathrm{R}$ squared value is 0.584 , which means that the effect of the independent variables on the purchase of beef products is $58.38 \%$ and the rest is explained by other independent variables that are not included in the model.

Independent variables that have a positive and very real effect, namely mother's education $(\mathrm{P}<0.01)$ and income have a significant effect $(\mathrm{P}<0.05)$ on the purchase of beef. Mother'education and household income are influential and interrelated because if the income increases and the mother's education is high, then it will try to allocate funds for the purchase of beef which is useful as a source of animal protein. Income owned by consumers is a resource that can be used to meet food needs including beef [10]. Income is closely related to a person's purchasing power for a product that is consumed. The higher the income of beef consumers, the greater the opportunity for consumers to buy quality beef. People with high incomes will tend to consume more [1112]. However, it is different from the research results from [13] which states that the greater the level of income, the demand for beef will decrease. It is assumed that with higher income levels, consumers will tend to choose foods that are more varied and nutritious, so that the food consumed tends to be chosen not necessarily by consuming beef. Even though the mother's education is high, namely high school, but due to the relatively low income (IDR 2.860.750 $\pm 2.258 .450 /$ month). Locations in rural and sub-urban areas where the husband's occupation 
varies, among others, as farmers, laborers, and traders and a small part as civil servants and private banks. The survey results show that many of the businesses undertaken by mothers cannot run businesses due to the impact of health protocol rules and at work they still have to accompany their children to school online which require parental supervision and assistance. The expenditure for purchasing beef is still low (IDR 100.000-200.000/month). Consumers are mostly not consuming beef. Frequency of purchase only one week/month. Based on the results of a survey of consumers consuming beef on the day of Qurbani, the rest they choose to buy other protein sources

\section{CONCLUSION}

During the pandemic, consumers choose to buy fresh beef directly at the market and some choose processed meat, namely meatballs and sausages. Mother's income and education affect the purchase of beef. On the other hand, it is necessary to improve health protocols to be firmer in the market because of the high interest in purchasing products directly to the market.

\section{ACKNOWLEDGMENTS}

The authors would like to thank Universitas Gadjah Mada for the funding support of the research through "Laboratory Thematic Grant number 1799 / J01.1.25 / KU / 2020. Thank you also to the respondents of the households in Depok District.

\section{REFERENCES}

[1] Kusmaria, Susanti, Fitri A, and Handayani S. 2020. Kajian Kebijakan Daging Sapi Di Indonesia Untuk Mendukung Swasembada Daging Sapi DwijenAGRO. 10 27-39.

[2] Mauludu M A. 2020. Dampak Physical Distancing Terhadap Kemampuan Sosial Pemuda J. Behav. Ment. Health. 1 76-81

[3] Purwanto E, Alfathan M F, Embunsari M I, Astridayanti N, Aprilya S, and Hamzah E D. 2021. Jurnal Ilmu Pengetahuan, Teknologi, dan Seni bagi Masyarakat. 10 58-69.

[4] Gujarati D N. 2013. Basic Econometric. (New York: Mc Graw-Hill Company).

[5] Ratnawati, Nurliana, and Razali. 2014. Tingkat Kepuasan Konsumen Terhadap Kualitas dan Harga Daging Sapi Yang Dijual di Kota Banda Aceh Jurnal Agripet. 14 125-131.

[6] Simarmata L, Osak R E M F, Ondoh E K M, and Oroh F N S. 2019. Analisis Preferensi Konsumen Dalam Membeli Daging Broiler Di Pasar Tradisional Kota Manado (Studi Kasus "Pasar
Pinasungkulan Karombasan") Zootec. 39 194202.

[7] Muzayyanah M A U, Syahlani S P, Dewi N H U, and Wahyuni E. 2021. Consumer Purchasing Behavior: An Empirical Study Of Livestock Products Food. In: IOP Conf Series: Earth and Environmental Science. 686 1-6.

[8] Amalia S R, Bahar A, Suhartiningsih, and Soeyono R D. 2021. Faktor Penentu Pemilihan Produk Pangan Beku (Frozen Food) Pada Generasi Y Dan Z Di Masa Pandemi Covid-19 Jurnal Tata Boga. 10 213-222.

[9] Girsang V I, Harianja E S, and Purba I E. 2020. Pencegahan Covid-19 Pada Pedagang Pasar Karya Wisata Kelurahan Gedung Johor Jurnal Abdimas Mutiara. 1 206-213.

[10] Wirahady N and Isra G A. 2021. Faktor-faktor yang Mempengaruhi Jumlah Pembelian Daging Sapi di Pasar Sentral Kota Makassar Jurnal Peternakan Lokal. 3 29-33.

[11] Ansyarif H, Susilowati S, and Octavia R P. 2021. Faktor-faktor yang Mempengaruhi Tingkat Preferensi Konsumen Dan Pengambilan Keputusan dalam Memilih Daging Sapi di Pasar Tradisional Kecamatan Sape, Kabupaten Bima Jurnal Dinamika Rekasatwa. 4 155-166.

[12] Sitinjak W and Tanjung J A. 2020. Faktor-Faktor Yang Mempengaruhi Permintaan Daging Sapi Di Kota Pematangsiantar (Studi Kasus Pasar Horas Di Kota Pematangsiantar) Jurnal Agrilink. 2 8694.

[13] Purnama S M, Wibowo R, and Kusmiati A. 2016. Faktor-faktor yang mempengaruhi permintaan dan perilaku konsumen rumah tangga terhadap daging sapi di Kabupaten Jember J. Soc. Agric. Econ. 9 8-22. 